\title{
Mrica Reservoir Sedimentation: Current Situation and Future Necessary Management
}

\author{
Puji Utomo \\ Civil Engineering Department, University of Technology Yogyakarta, Yogyakarta, INDONESIA \\ mr.pujiutomo@gmail.com
}

\begin{abstract}
Mrica Reservoir is one of many reservoirs located in Central Java that experienced a considerably high sedimentation during the last ten years. This condition has caused a rapid decrease in reservoir capacity. Various countermeasures have been introduced to reduce the rate of the reservoir sedimentation through catchment management and reservoir operation by means of flushing and/or dredging. However, the sedimentation remains intensive so that the fulfillment of water demand for electrical power generation was seriously affected. This paper presents the results of evaluation on the dynamics of the purpose of this research is to evaluate the sediment balance of the Mrica Reservoir based on two different scenarios, i.e. the existing condition and another certain type of reservoir management. The study on sediment balance was carried out by estimating the sediment inflow applying sheet erosion method in combination with the analysis of sediment rating curve. The measurement of the deposited sediment rate in the reservoir was conducted through the periodic echo sounding, whereas identification of the number of sediment that has been released from the reservoir was carried out through the observation on both flushing and dredging activities. The results show that during the last decade, the rate of the sediment inflow was approximately 5.869 $\mathrm{MCM}$ /year, whereas the released sediment from the reservoir was $4.097 \mathrm{MCM} / \mathrm{year}$. In order to maintain the reservoir capacity, therefore, at least $1.772 \mathrm{MCM} /$ year should be released from the reservoir by means of either flushing or dredging. Sedimentation management may prolong the reservoir's service life to exceed the design life. Without sediment management, the lifetime of the reservoir would have finished by 2016, whereas with the proper management the lifetime may be extended to 2025.
\end{abstract}

Keywords: Sedimentation, sediment balance, remaining life, sedimentation management

\section{INTRODUCTION}

Reservoir sedimentation is an important issue that should be mitigated to sustain the reservoir to remain function properly. Excessive sedimentation would make its service life shorter than its design life. Almost all of reservoirs in Indonesia including Mrica Reservoir have been experiencing sedimentation. This happens probably due to high land erosion as resulted from the heavy rainfall occurrence and also the human interfere (such as deforestation and other land cultivation). The previous study showed that the yearly sediment production from the land reaches up to $7.358 \mathrm{MCM} /$ year (Setiawan, 2015).Other studies showed that the service life of the reservoir tends to decrease rapidly (Malik, 2006; Wulandari, et al, 2015; and Nugraha, 2015). Unless a proper management is introduced, the service life of Mrica Reservoir may end at 2022 (Jasa Tirta I Public Corporation, 2015). It was reported in the latest aforesaid study that from 1982 until 2014, an amount of $106.26 \mathrm{MCM}$ of sediment has entered the reservoir. At the present condition, the capacity of the reservoir is only approximately $28.3 \%$ and $11.3 \%$, both of the total storage and dead storage capacity respectively.
Efforts in introducing the better sedimentation management have been made by Jasa Tirta I Public Corporation through the integration of upper catchment, streams and reservoir management. The upstream catchment management is all activities related to land conservation that is aimed at minimizing the sediment production, whereas stream management is trapping the sediment by means of constructing the check dams. The reservoir management is all types of efforts to minimize the sediment settling in the reservoir by means of flushing or evacuating the sediment from the reservoir by means of dredging.

Knowing the importance of reservoir sedimentation management, the objectives of this study are to identify the existing sediment balance and prediction of the remaining reservoir service life of the Mrica Reservoir and to determine the optimum level of the plan of the integrated sediment management of the Mrica Reservoir and its corresponding useful life. 


\section{SEDIMENTATION STUDIES OF MRICA RESERVOIR}

There were several studies on Mrica Reservoir sedimentation during 1988 - 2015. The average erosion rate was estimated to be $2.46 \mathrm{~mm} /$ year (CV. Widha, 1988). Another institution (Ministry of Public Works) was $4.85 \mathrm{MCM} /$ year or equivalent to 4.0 $\mathrm{mm} /$ year. Other study showed that the erosion rate was found to be $4.77 \mathrm{~mm} /$ year on Merawu watershed, 3,1 mm/year on Serayu watershed, and $2.7 \mathrm{~mm} /$ year on outside the Merawu and Serayu watersheds. Until the end of 2014 , the data showed that $73.33 \%$ of the reservoir storage was filled with sediment (Jasa Tirta I Public Corporation, 2015). The research of Malik (2006) showed that the service life of Mrica Reservoir, based on the dead storage method, is 10.43 years; and 41 years, if based on the empirical area reduction method. Wulandari, et al. (2015) predicted that the reservoir useful life was 30 years, only half compared with that of 60 years of the design useful life.

The combination of land conservation and Sabo construction could prolong the reservoir useful life from 34 years to 47 years (Fauzi, 2006). Other study showed that the flushing activity only contributed 0.0175 efficiencies (Krisetyana, 2008). Setiawan (2011) conducted the review on sedimentation control through the check dams or sediment control structures combined with other land use management. The development of 1-2 unit/year of check dam could reduce the sedimentation at $51,000 \mathrm{~m}^{3} /$ year while the vegetation development of $1.26 \%$ per year could reduce the sedimentation at $216,000 \mathrm{~m}^{3} /$ year.

\section{CATCHMENT EROSION AND FIELD MEASUREMENTS}

\subsection{Catchment Erosion}

The prediction that still popular and commonly used for average erosion rate from the certain watershed is the Universal Soil Loss Equation (USLE) method with its various modifications and development, which is as follows:

$A=R \times K \times L \times S \times C \times P$

where $A$ is the amount of soil loss (ton/ha/year or $\mathrm{mm}$ /year), $R$ is the rainfall factor, $K$ is the soil type factor, $L$ is the slope length factor, $S$ is the slope gradient factor, $C$ is the soil vegetation cover and crop management factor, and $P$ is the land conservation special treatments factor. Based on prediction with USLE method, the total of soil loss in an erosion process would determine a danger level of erosion in a watershed, as seen in Table 1.
The previous study on the estimation of the catchment erosion of Mrica Reservoir (applying USLE method for 1989 to 2014 rainfall data) has found the average annual catchment erosion, i.e. 81.12, 185.12 and 52.16 ton/ha/year for Serayu, Merawu and Lumajang catchment area, respectively (Indonesian Power Company, 2015).

Table 1.Classification of erosion danger level (Department of Forestry, 2009)

\begin{tabular}{lll}
\hline $\begin{array}{l}\text { Erosion } \\
\text { Danger Level }\end{array}$ & $\begin{array}{l}\text { Soil loss (A) in } \\
\text { (ton/ha/year) }\end{array}$ & Note \\
\hline I & $<15$ & very light \\
II & $15-60$ & light \\
III & $60-180$ & medium \\
IV & $180-480$ & heavy \\
V & $>480$ & very heavy \\
\hline
\end{tabular}

\subsection{Related Field Studies}

The rate of reservoir sedimentation may be studied through the field measurements both on the reservoir (by means of echo sounding) and on the rivers entering the reservoir (by mean bed load and suspended load sampling). The echo sounding is basically carried out to identify the elevation of the reservoir bed and hence the bathymetrical condition. Further analysis of bathymetrical condition would give the reservoir storage information or the reservoir characteristics at a particular period. The rate of reservoir sedimentation may through the periodical measurement of echo soundings.

Another method to identify the rate of reservoir sedimentation is by measuring the sediment transport in the mouth of rivers which flow into the reservoir. The total sediment entering the reservoir is the amount of suspended load and bed load those are measured at the river mouth. Measurement of suspended load in various flow conditions may lead us to establish the sediment rating curve. By utilizing the established sediment rating curve, total sediment transport then is easy to be estimated. Sediment concentration can be also be estimated using an empirical formula developed by some researchers, such as Meyer \& Muller (1948), and Graf \& Altinakar (1998). In the case of rivers entering the Mrica Reservoir, the utilization of Equation (2), (3) and (4) are justifiable (Indonesian Power Company, 2015).

Serayu River $\quad: Q_{s}=0.756 \times Q_{w}{ }^{2.084}$

Merawu River $\quad: Q_{s}=26.525 \times Q_{w}{ }^{1.745}$

Lumajang River $\quad: Q_{s}=11.7372 \times Q_{w}{ }^{2.8864}$

where $Q_{s}$ is the sediment transport in river $(\mathrm{kg} / \mathrm{s})$ and $Q_{w}$ is the water discharge of river $\left(\mathrm{m}^{3} / \mathrm{s}\right)$. 
The above study also stated that the concentration of mean suspended load in a year was approximately $0.11 \%, 0.30 \%$ and $0.05 \%$ in Serayu River, Merawu River, and Lumajang River, respectively (Indonesian Power Company, 2015).

\section{SUDIRMAN DAM (MRICA RESERVOIR)}

Mrica Reservoir was built on 1983 and started to operate in 1988. The useful life of the reservoir was designed to be 60 years, i.e. up to the year 2049 . Geographically, the reservoir is located in $7^{\circ} \mathrm{S}$ and $110^{\circ} \mathrm{E}$. Administratively, the Mrica is located in the Bawang District, Banjarnegara Regency, Central Java. Mrica Reservoir was built on Serayu River of Serayu Bogowonto Basin, where catchment area of Mrica Reservoir is $957 \mathrm{~km}^{2}$ and the storage capacity is 193.5 MCM (see Figure 1). The Mrica Reservoir has 3 turbines for hydroelectric power plant which could generate electric power of 580,000 MWH per year. The annual mean land erosion rate in the watershed of Mrica Reservoir reached $6.052 \mathrm{~mm} /$ year. If the Mrica watershed area is $904.91 \mathrm{~km}^{2}$, then the annual mean land erosion rate reached 5.477 million $\mathrm{m}^{3} /$ year. If it is assumed that the soil specific gravity value $(\Upsilon b)=1.8$ ton $/ \mathrm{m}^{3}$, the annual mean land erosion reached 108.938 ton/ha/year. Based on the watershed danger level classification published by the Forestry Department (2009), the potency of the land erosion is in category III or middle (between 60-180 ton/ha/year).

\subsection{Sediment Deposited in the Reservoir}

The result of the analysis showed that the reservoir sedimentation rate varied considerably from year to year. The highest sedimentation rate occurred in 2000, that of $7.027 \mathrm{MCM} / \mathrm{year}$. The lowest sedimentation rate occurred in 2014, that of $1.708 \mathrm{MCM} /$ year. Meanwhile, the annual mean sedimentation rate reached to some amount of $4.097 \mathrm{MCM} / \mathrm{year}$.

\subsection{Sediment Inflow to the Reservoir}

The accumulation of suspended load and bed load is the total annual sediment that was predicted to enter the reservoir. The number of total sediment that used the rating curve method and estimated with Maddock table was relatively higher, whereas the total annual mean sediment that entered was predicted to be 6.001 million $\mathrm{m}^{3} /$ year. The Sediment Delivery Ratio (SDR) of the Mrica Reservoir varies from $43.45 \%$ to $132.23 \%$. Some studies found that average SDR Mrica Reservoir reached the number of 0.748 or $74.81 \%$.

\subsection{Sediment Outflow from the Reservoir}

Estimation on the sediment outflow from the reservoir was conducted during 1992 thru 2015 by the calculation of the sediment volume obtained from flushing activities. Based on flushing activities during 1992-2015, the average annual sediment outflow was approximately 0.419 million $\mathrm{m}^{3} /$ year. Whereas based on flushing activities in 2001 to 2015 , the average annual sediment outflow was 0.521 million $\mathrm{m}^{3} /$ year.

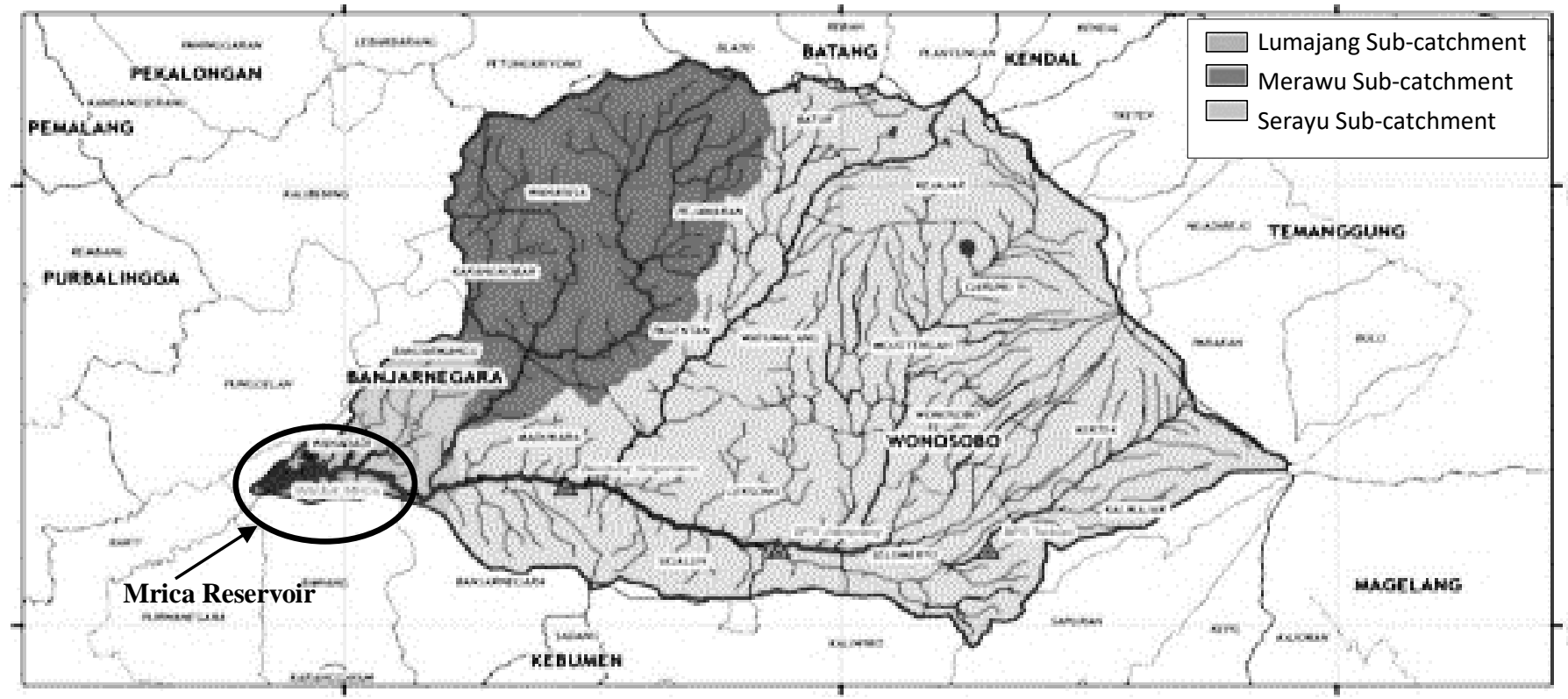

Figure 2. Catchment area of Mrica Reservoir 
Apart from the flushing activities, the sediment outflow was also observed in the form of sand mining activities. According to the observation during 2010 thru 2015, the sand mining activities took place in several villages such as Pucang, Semampir, Wangon, and Jenggawur. The average annual sediment outflow from these sand mining activities was found to be approximately $145,617 \mathrm{~m}^{3} /$ year. The sediment concentrations that passed through the intake power and the irrigation were considered to be the same. Comparison of the annual discharge between ones that passed through the intake power, irrigation outlet, and spillway runoff are $87.48 \%, 12.25 \%$, and $0.27 \%$, respectively (Utomo, 2017). The sediment balance of the Mrica Reservoir was then presented in the form of distribution of sediment flow as shown in Table 2.

Table 2. Distribution of average annual sediment balance

\begin{tabular}{|c|c|c|}
\hline No. & Description & $\begin{array}{c}\text { Volume } \\
\left(\mathrm{m}^{3}\right)\end{array}$ \\
\hline 1 & Sediment deposited in reservoir & $3,850,015$ \\
\hline 2 & Sediment outflow from Flushing & 521,123 \\
\hline 3 & Sediment outflow from Intake & $1,298,138$ \\
\hline 4 & Sediment outflow from Irrigation & 181,701 \\
\hline 5 & Sediment outflow from Spillway & 4,003 \\
\hline 6 & Sediment outflow from Sand mining & 145,617 \\
\hline \multicolumn{2}{|r|}{ Total Sediment that entered the reservoir } & $6,000,597$ \\
\hline
\end{tabular}

\section{SEDIMENTATION MANAGEMENT AND FLOOD CONTROL IMPACT}

\subsection{Existing Management}

The simplest calculation of remaining life was based on the sedimentation rate in the dead storage area. The echo sounding measurement on 2015 showed that the dead storage volume was 8,102 million $\mathrm{m}^{3}$, while the mean sedimentation rate was $3,477 \mathrm{~m}^{3} /$ year, then the remaining life of the reservoir could be obtained, as follows:

$$
n=8,102 / 3,477=2.330 \text { years }
$$

From the calculation, the remaining life is still 2.330 years, calculated from year 2015 or up to 2017.Based on the regression analysis, the reservoir life was still another 2 years left, which calculated from 2015 or up to 2017. The remaining useful life of the reservoir with curve fitting linear method is shown in Figure 4.

It is seen from Figure 4 that the decrease of the storage capacity was lasting very rapidly that the total and dead storage capacity in 2014 were left $28 \%$ and $11 \%$ respectively. Considering the specific condition the reservoir characteristic in 1988, 2004 and 2014, the decrease of the storage volume for the entire elevation were also very significant, even the life of the reservoir was not yet 20 years (see Figure 5).

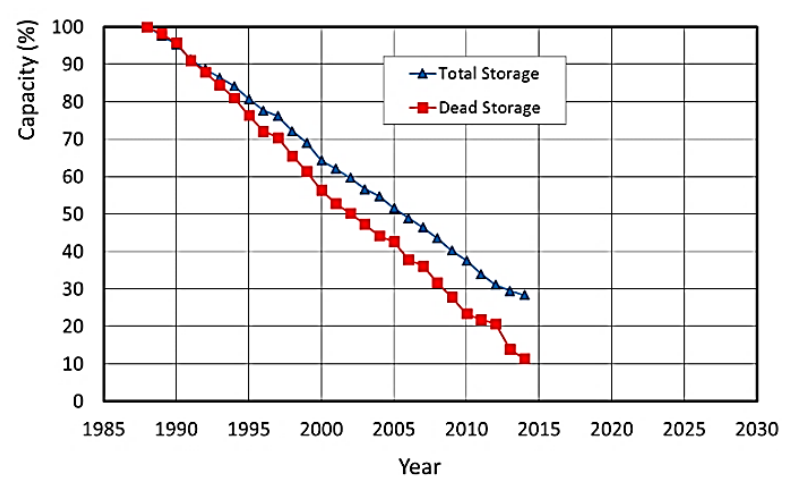

Figure 4. The decrease of the reservoir storage capacity (1988 - 2014)

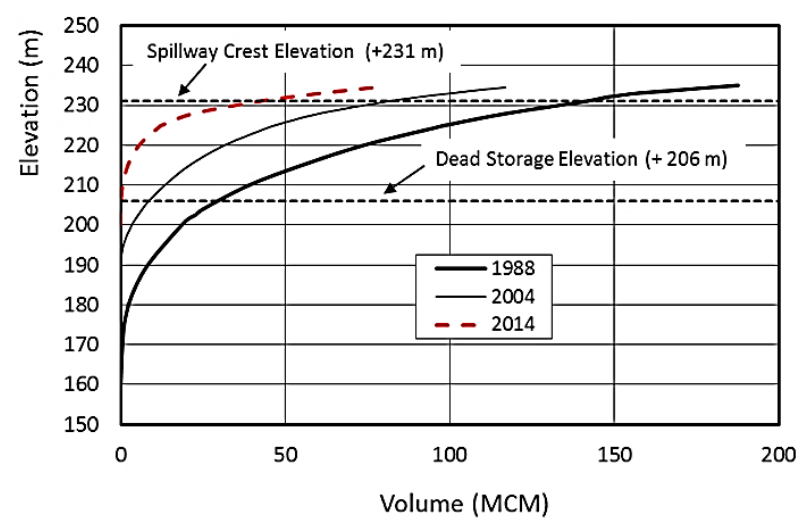

Figure 5.Storage characteristic of Mrica Reservoir

It could be seen clearly from Figure 5 that in 2014, the reservoir storage volume at the elevation $+206 \mathrm{~m}$ was relatively small or close to zero. The same 2014 condition also showed that the total storage capacity, i.e. at the elevation $+231 \mathrm{~m}$, decreased from 140.00 MCM until less than 50.00 MCM. Such situation showed that the drastic increase in the reservoir bed elevation has taken place. Even the reservoir life is just 26 years. This situation showed that the reservoir sedimentation has been taking place in a very excessive way. Further analysis of the sediment balance presents the average annual sediment balance at the current or the existing management (Figure 6).

It is obvious that the catchment erosion of 5.537 MCM per year is considered very high that all efforts to reduce the sediment entering the reservoir by means of dredging, flushing and mining activities were not sufficient. It is seen from Figure 6 that under the current sedimentation management, the average annual reservoir sedimentation of $4.087 \mathrm{MCM}$ per year may contribute disturbances to the reservoir performance. 


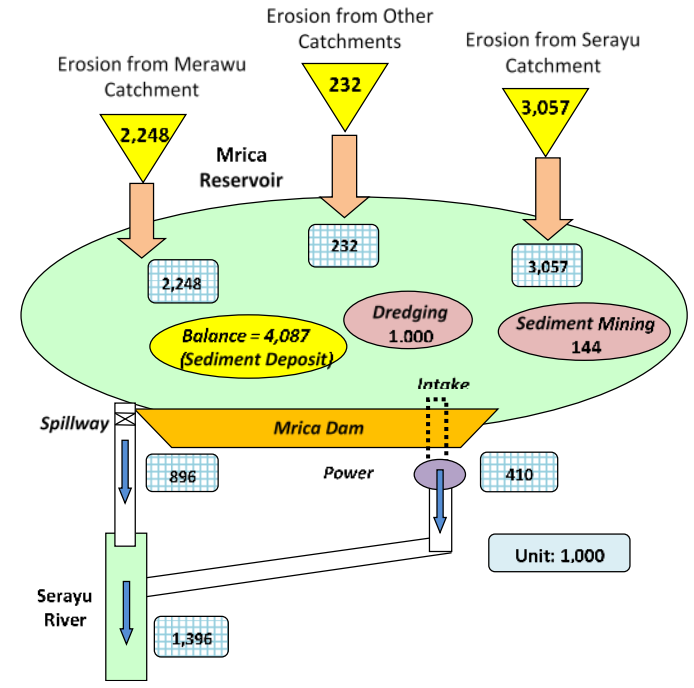

Figure 6. Average annual sediment balance in current (1988-2014) sediment management

\subsection{Necessary Future Management}

By neglecting the economic consideration, some conceptual thinking's to maintain the sustainability of the Mrica Reservoir should be adopted. In almost all of the conceptual thinking being introduced, further action on implementing the zero sediment balance should be made applicable. There are two questions then, whether the current capacity should be enlarged or should sufficiently be remained is it is. Based on the obvious condition that the current activities in maintaining the sedimentation have been considerably complex, the second conceptual thinking seems to be more implementable. The sediment management on Mrica Reservoir may comprise of two ideas, firstly keeping the storage capacity (both total and dead storage capacity) to remain as 2014 condition (see Figure 7), and secondly, implementing program towards the zero sediment depositing in the reservoir (see Figure 8). The first attempt could not be achieved straightly after 2014 since the this needs a gradual process. The more important consideration is to create the condition that any treatment being introduced the reservoir storage would not be lower than $28 \%$ and $10 \%$ for the total and dead storage respectively. The second attempt, i.e. the implementation of zero sediments entering reservoir that may comprise of the following activities;

a) upper catchment conservation,

b) increase flushing and

c) increase sand mining activities.

Upper catchment conservation activities comprise of activities related to sheet erosion control by means of vegetation works (reforestation and other land cultivation) and civil works (construction of gully plugs and sediment control structures). The aforesaid conservation program should be addressed at reducing the land erosion at $1.102 \mathrm{MCM}, 0.1 \mathrm{MCM}$ and 1.625 MCM per year for the catchment of Merawu, Serayu, and others respectively. Accordingly, the flushing and sand mining activities should also be increased at another $0.431 \mathrm{MCM}$ and 1,167 MCM per year respectively.

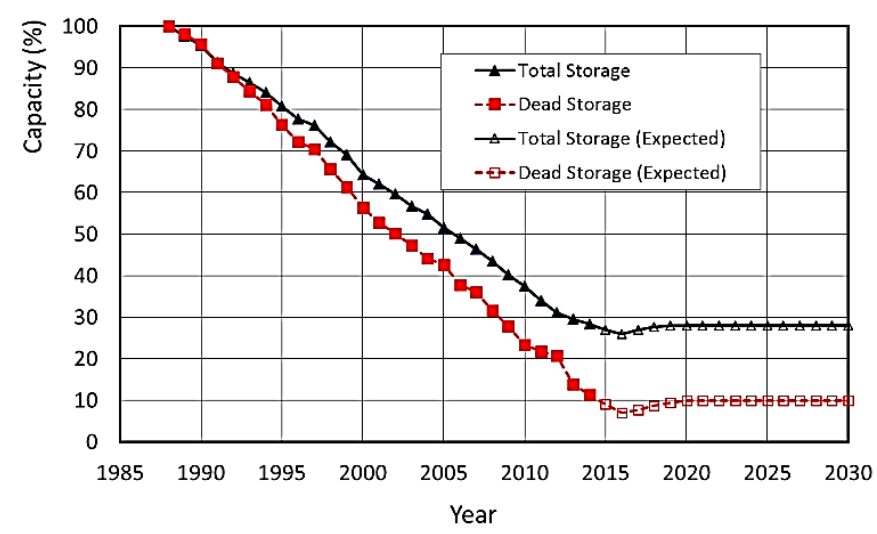

Figure 7. The decrease (1988-2014) and the future (20152030) storage capacity of Mrica Reservoir

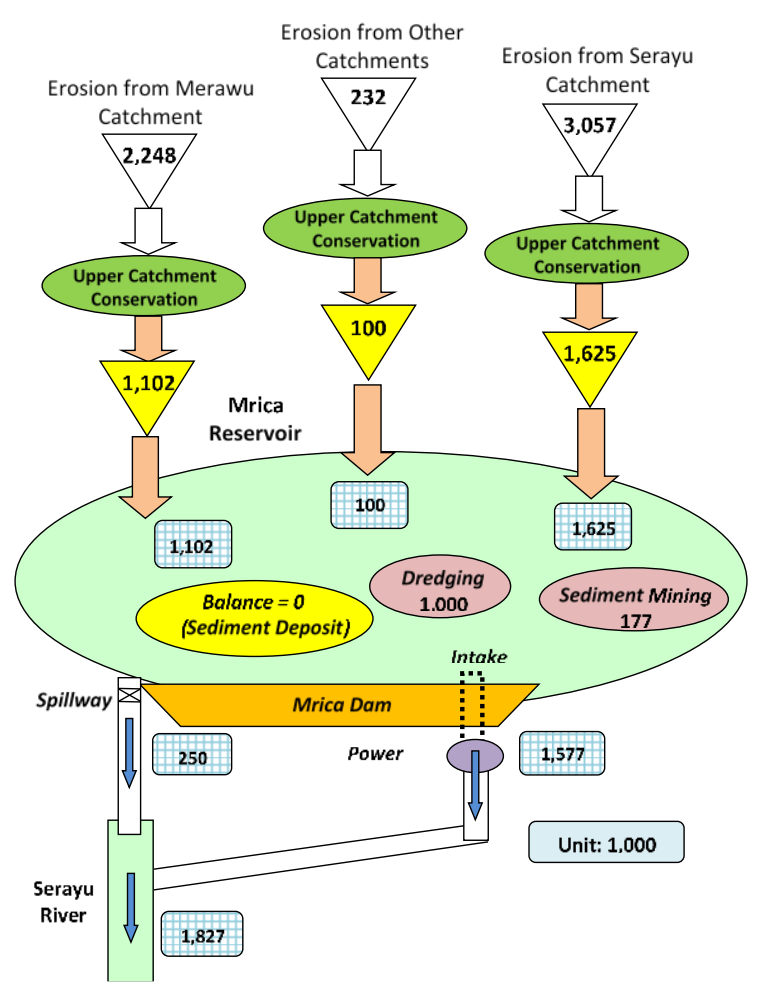

Figure 6. Average annual sediment balance in future (20152030) sediment management of Mrica Reservoir

\section{CONCLUSIONS AND RECOMMENDATIONS}

\subsection{Conclusions}

The average annual sediment inflow under the current sedimentation management of Mrica Reservoir seems very excessive that the decrease in both total storage and dead storage still take place very rapidly. In order 
to keep maintaining the reservoir volume as it was in 2014, some sediment volume, i.e. approximately 4.087 MCM per year, should be stopped before entering the reservoir by means of conservation program at upper catchments, or otherwise evacuated from the reservoir by means of dredging. Further intention to avail more storage larger than it was in 2014 condition requires more complexity in the management.

\subsection{Recommendations}

Bearing in mind that the current management of the Mrica Reservoir has been actually complex (Indonesia Power, 2015), a combination of the upper catchment management, reservoir operation (sluicing and flushing) and also evacuating the sediment from the reservoir is advisable. However, the monitoring and evaluation of the activities in such structured, integrated and implementable manner are considered essential.

\section{REFERENCES}

CV. Widha, 1988. Erosion and Sedimentation Research in Serayu Watershed, Mrica Hydraulic Power Plant, Banjanegara: CV Widha.

Department of Forestry, 2009. P. 32/MenhutII/2009 Tata Cara Penyusunan Rencana Teknik Rehabilitasi Hutan dan Lahan Daerah Aliran Sungai [Guideline for Forest and Watershed Rehabilitation Planning (RTkRHL-DAS)], Jakarta: Ministry of Forestry.

Fauzi, B. A., 2006. Management of Sedimentation in Panglima Besar Reservoir, Yogyakarta: Civil Engineering Department Universitas Gadjah Mada.

Graf, W. H. \& Altinakar, M. S., 1998. Fluvial Hydraulics. Chichester, England: John Wiley \& Sons, Ltd.

Indonesian Power Company, 2015. Laporan Pelaksanaan Penyelidikan Sedimentasi Waduk [Report of Investigation of Reservoir Sedimentation], Banjarnegara: Indonesian Power Company.

Jasa Tirta I Public Corporation, 2015. Roadmap of How to Manage Sedimentation in Mrica,
Wadaslintang and Sempor Reservoir in Bogowonto Watershed. Malang, Indonesian Water Corporation.

Krisetyana, H., 2008. Tingkat Efisiensi Penggelontoran Endapan Sedimen di Waduk PLTA $P B$ Soedirman, Semarang: Civil Engineering Department Universitas Diponegoro.

Malik, D. J., 2006. Prediction Remaining Life of Mrican Reservoir in Banjarnegara Central Java with Dead Storage Capacity Method and Empirical Area Reduction, Purwokerto: Civil Engineering Department Universitas Jendral Soedirman.

Meyer, P. E. \& Muller, R., 1948. Formula for Bed Load Transport. Stockholm, Proceedings 3rd Meeting of IAHR.

Nugraha, A. A., 2015. Study on the Performance of Wonogiri Reservoir as Flood Control Structure. Journal of the Civil Engineering Forum, 1(3), pp. 8592. doi: 10.22146/jcef.24007

Setiawan, C., 2011. Kajian Pengendalian Sedimentasi di Waduk PB. Soedirman dengan Bangunan Pengendali Sedimen dan Pengaturan Tata Guna Lahan [Study on Sedimentation Management at PB. Soedirman Dam and Land Use Control], Yogyakarta: Civil Engineering Department Universitas Gadjah Mada.

Utomo, P., 2017. Kajian Imbangan Sedimen dan Sisa Umur Layanan di Waduk Mrica, Banjarnegara, Jawa Tengah [Investigation of Sediment Balance and Design Life of Mrica Reservoir], Yogyakarta: Master Thesis. Faculty of Engineering, Universitas Gadjah Mada.

Wulandari, D. A., Legono, D. \& Darsono, S., 2015. Evaluation of Deposition Pattern of Wonogiri Reservoir Sedimentation. International Journal on Civil and Environmental Engineerung - International Journal of Engineering and Sciences. Paper ID:153202-7474-IJCEE-IJENS 